\title{
Fixtures in the Landlord-Tenant Relationship
}

A lease is an agreement by which a tenant is allowed temporarily to exploit a landowner's property for his own benefit. Since the land itself is but one of several factors in the production of wealth, ${ }^{1}$ the tenant may have to employ such additional resources as manpower, machines, or buildings in order to derive income from the use of the premises. ${ }^{2}$ The law of fixtures, which deals with property rights in chattels affixed to the land, ${ }^{3}$ determines the interests of the parties in a large portion of these added resources.

This comment analyzes the economic effect of the law of fixtures on the landlord-tenant relationship. It first shows that fixtures law has been used in the past as a device for implementing the economic objectives of protecting the landlord, encouraging the tenant's commercial activity, and promoting the public interest in conserving land resources. It then examines these functions in the light of modern technological advances and techniques of capital management. The results of this examination suggest ( 1 ) that the protection of the landlord can be accomplished more effectively by replacing existing fixtures tests with a system in which the tenant compensates the landlord for the physical damage to the freehold caused by removal; and (2) that it is no longer necessary to interject considerations of conservation and economic efficiency into landlord-tenant fixtures law.

\section{Conflicting Economic Objectives}

The legal rules which govern tenants' rights to the wealth added to the leasehold are often a product of the general economic objectives that the law seeks to achieve. The conflicting economic considerations

1 See Ely \& Warren, LaNd Economics 113-17 (1940).

2 When property such as a furnished apartment is rented for consumer purposes, comparatively few additions are usually made. Even in this case, however, appliances and furnishings may be added or existing items replaced.

3 A fixture is a chattel which, while retaining its separate physical identity, is associated in some manner with realty. Depending on the legal relationships between the parties involved, it may be considered as either real or personal property. See generally 5 American Law of Property § 19 (Casner ed. 1952); Brown, Personal Property \$§ 137-57 (2d ed. 1955); 5 Powerl, Real Property If 651-60 (1962); Bingham, Some Suggestions Concerning the Law of Fixtures, 7 Colum. L. REv. I (1907); Horowitz, The Law of Fixtures in California-A Critical Analysis, 26 So. CAL. L. REv. 21 (1952); Niles, The Intention Test in the Law of Fixtures, 12 N.Y.U.L. REv. 66 (1934). 
that underlie problems of tenants' fixtures today are reflected in the development of the common law in three areas: the "attachment" test in the law of fixtures, used to conserve land resources; the trade fixtures exception to the attachment test, used to stimulate commercial exploitation of the leased property; and the rules of waste, used to protect the interests of the landlord.

\section{Conserving Land Resources: The Attachment Test}

Many of the early fixtures cases were contests between the heir of a landowner, who claimed a fixture as part of the realty, and the deceased's executor, who claimed it as personalty. Adopting the Roman maxim, "whatever is attached to the land becomes land," the English courts generally held that anything connected to the freehold was realty and therefore belonged to the heir. ${ }^{5}$ An opinion in one of the early decisions recognized the economic waste involved in dismantling a functioning economic unit: "[W] hen [chattels] are fixed they are for the continual profit of the house; and therefore it is more reasonable that the heir should have them, to whom the freehold to which they are joined belongs, than the executors, who have nothing to do with the freehold." 6

The liberality of the common law in favor of the heir reflected in public policy the economic fact that it may be wasteful to allow the removal of valuable annexations from the land. ${ }^{7}$ An integrated, func-

4 The transformation of the Roman aphorism into a rule of law is generally considered to be based on a misunderstanding of the Roman law of accession. See Niles, The Rationale of the Law of Fixtures: English Cases, II N.Y.U.L. REv. 560, 561-64 (1934).

5 See Y.B. Mich. 20 Hen. 7, 13, pl. 24 (1505) (furnace connected to a wall was realty); Y.B. Trin. 21 Hen. 7, 26, pl. 4 (1506) (furnace resting on the ground and vats on the floor of a brewhouse were realty).

6 Y.B. Trin. 21 Hen. 7, 27, p1. 4 (1506) (Kingsmil, J.), quoted in Amos \& Feraro, FIXTUREs 153 (2d ed. 1847).

7 From an economic point of view, it is meaningless to divide a unit of property into the value of the land and the value of a building or other annexation. The analysis below is adopted from Turvex, The Economics of ReAl Property 23 (1957):

The following magnitudes can be ascertained or estimated:

$T=$ the market value of the building on a site,

$R=$ the replacement cost of the building,

$T^{\prime}=$ the market value the property would have if the building on it were new and represented the highest and best (most profitable) use of the site,

$C=$ the cost of constructing such a building,

$S=T^{\prime}-C$, market value of the site.

If $S$ exceeds $T$ by more than the cost of demolition (net of scrap value), it will pay to demolish the building. Thus, it might be said that $T$ could be divided into $S$ and $(T-S)$, the value of the building, since if $(T-S)$ is positive, it represents the sum which would justly compensate the owner for removal of the building. Nobody, however, will ever offer to pay $(T-S)$, so it is not in any sense a "market" value. In short, since a building must 
tioning economic unit has a "going value"s that is greater than the value of the sum of its component parts. By adopting a rule in inheritance cases that restricted the removability of annexations, the English courts attempted to preserve this "going value."

The early common law made no distinction between chattels affixed to the land by a deceased landowner and chattels added by a tenant for years. The maxim "whatever is attached to land becomes land" was rigorously applied against tenants, ${ }^{10}$ and decisions in landlord-tenant cases were frequently based on whether the particular annexation would be "realty" if the contest were between an heir and an executor. ${ }^{11}$ The property interest of the tenant in his annexation was thus subordinated to the public policy formulated in the inheritance cases of conserving land resources.

\section{Encouraging Trade: The Trade Fixtures Exception ${ }^{12}$}

As fixtures law developed, English courts modified the attachment rule with respect to fixtures attached by a tenant "for the convenience of his trade."13 The exception to the general conservation policy of the

ordinarily be used in conjunction with land, it cannot be bought and sold as if it were floating in air.

Alternatively, it might be said that $T$ could be divided between $R$, the value of the building, and $(T-R)$, the value of the site. However, since an old building may be as useful for certain purposes as a new one, $R$ may be irrelevant to any proposed action, and thus it cannot be called a "market" value.

8 Cf. Banner Milling Co. v. State, 240 N.Y. 533, 544, 148 N.E. 668,672 (1925), assessing damages in condemnation proceedings: "The claimant is entitled to compensation, not merely for so much land, so much brick, lumber, materials and machinery considered separately, but if they have been combined, adjusted, synchronized and perfected into an efficient functioning unit of property, then it must be paid for that unit .... In that limited sense, it is entitled to the 'going value' . . . of its physical property."

"A desire to maintain the "going value" of a unit of land appears to have influenced the judicial response to various problems of fixtures law. See, e.g., Voorhis v. Freeman, 2 W. \& S. 116 (Pa. 1841), in which the Pennsylvania "industrial plant" doctrine was formulated to protect a going business concern from attaching creditors. In holding that the real estate mortgage of a factory included machinery that was not annexed to the freehold, the court emphasized that selling individual pieces of the going unit would cause economic loss. Id. at 119.

10 A tenant was guilty of waste when he removed chattels which he had annexed to the freehold. Coke, Commentary on Lirtleton *53a.

11 See Herlakenden's Case, 4 Co. Rep. 62a, 63b, 76 Eng. Rep. 1025, 1030 (K.B. 1589).

12 The term "trade fixture" is used by different courts with various meanings. See, e.g., Sherburne Corp. v. Town of Sherburne, 124 Vt. 481, 483, 207 A.2d 125, 127 (1965): "Fixtures usually are classed as real estate; trade fixtures, an exception to the rule, are usually classed as personal property." As used in this comment, "trade fixture" refers to a chattel affixed to the land by a tenant for purposes of trade. No assumption is made as to whether it is realty or personalty. Cf. note 35 infra.

13 Poole's Case, I Salk. 368, 91 Eng. Rep. 320 (K.B. 1703). The court held that a soap 
attachment test was justified as encouraging the development of land resources for commercial purposes, "which is become the pillar of the state."14 As one court stated: "What tenant will lay out his money in costly improvements of the land, if he must leave everything behind which can be said to be annexed to it?"15

The trade fixtures exception was economically sound in the period of commercial growth during which the rule developed. ${ }^{16}$ Long term commercial leases, which today protect a tenant desiring to make large capital expenditures, were not widely used until the nineteenth century. ${ }^{17}$ Creditors of the tenant, lacking the protection of modern security devices, ${ }^{18}$ would have been less willing to extend credit when the tenant's property might become "realty" and therefore immune to attachment. ${ }^{19}$ Finally, the industrial development of the period caused a change in the relative value of the chattels brought onto the premises, thereby magnifying the hardship caused by losing attached items. ${ }^{20}$

\section{Protecting the Landlord: Rules Against Waste}

The law of fixtures was historically related to rules against waste designed to protect the landlord against injury to the realty. ${ }^{21}$ Early

maker could remove boiling vats during the leasehold term. However: "[T] difference between what the soap-boiler did to carry on his trade, and what he did to complete the house, as hearths and chimney-pieces, which [were] not removable." Ibid.

14 Penton v. Robart, 2 East 88, 90, 102 Eng. Rep. 302, 303 (K.B. 1801). See also Cameron v. Oakland County Gas \&. Oil Co., 277 Mich. 442, 452, 269 N.W. 227, 330 (1936): "The right of the tenant to remove the erections . . is one founded upon public policy ... that every person shall be encouraged to make the most beneficial use of his property the circumstances will admit of."

15 Penton v. Robart, 2 East 88, 90, 102 Eng. Rep. 302, 303 (K.B. 1801).

16 The growth of the exception is generally considered to have paralleled the emergence of the commercial class in England during the fifteenth century. See Casenote, 1 CALIF. L. REv. 192, 194 (1913). But cf. Niles, The Rationale of the Law of Fixtures: English Cases, 11 N.Y.U.L. REv. 560, $564 \mathrm{n.37}$ (1934) (arguing that the trade fixtures rule antedates the commercial development).

17 See Holdsworth, Historical Introduction to the LANd LAw 233 (1927). Compare the restrictive effect on agricultural tenants' investments where the prevailing tenancy is from year to year. Cotton, Regulations of Farm Landlord-Tenant Relationships, 4 Law \& Contemp. Prob. 508, 517 (1937).

18 See UnIform Commercial Code $\S 9$-313. Cf. Royal Store Fixture Co. v. Patten, 183 Pa. Super. 249, 130 A.2d 271 (1957), and Butler v. Butler's Diner, 81 R.I. 43, 98 A.2d 875 (1953), allowing creditors to remove buildings erected by the tenant.

19 The leading trade fixtures case involved a contest between a landlord and an attaching creditor of the tenant. Poole's Case, 1 Salk. 368, 91 Eng. Rep. 320 (K.B. 1703).

205 American Law of Property § 19.2, at 11 (Casner ed. 1952).

21 Both the law of fixtures and rules prohibiting a tenant's waste have their origins in common law actions for injury to real property. See Bronson, Frxtures $\S 4$, at 11 (1904). 
English cases held that when a tenant's chattel was placed on the leasehold in such a manner that its removal would cause damage to the landlord's building, it became a fixture and part of the freehold.22 If the tenant removed the item, he would be injuring the realty and therefore committing an act of waste. ${ }^{23}$

By making possible an action for waste when removal of a chattel would damage the premises, the law of fixtures furnished the landlord with legal ${ }^{24}$ and equitable ${ }^{25}$ devices for protecting the original value of the leasehold. As a result, it subordinated the tenant's interest in items attached to the premises to a policy of protecting the landlord's original investment in the land.

\section{Amerigan Fixtures Law: The Substantial Damage Test}

The leading American fixtures case of Teaff $v$. Hewitt ${ }^{26}$ was decided during a period of American judicial hostility to the harshness of the English attachment rule. ${ }^{27}$ The court in Teaff rejected attachment and based its decision as to when a chattel becomes realty upon

the intention of the party making the annexation, to make the article a permanent accession to the freehold-this intention being inferred from the nature of the article affixed, the relation and situation of the party making the annexation, the structure and mode of annexation, and the purpose or use for which the annexation has been made. ${ }^{28}$

22 See Amos \& Ferard, Fixtures 89 (2d ed. 1847).

23 See Coke, Commentary on Litrufton *53a. See also Graffell v. Honeysuckle, 30 Wash. 2d 390, 191 P.2d 858 (1948) and Roanoke Marble \& Granite Co. v. Standard Gas \& Oil Co., 155 Va. 249, 154 S.E. 518 (1930), holding a tenant guilty of waste for removing a fixture. At early common law, affixing the chattel was itself an act of waste. See 5 AMrRican LAw of ProperTy \& 20.11 (Casner ed. 1952).

24 See AMOS \& FERARD, FrxTURES 270-80 (2d ed. 1847).

$25 \mathrm{Id}$. at 281-88.

261 Ohio St. 511 (1853).

27 The trade fixtures exception to the attachment test was strictly limited to articles affixed for commercial and ornamental purposes. See Elwes v. Maw, 3 East 38, 102 Eng. Rep. 510 (K.B. 1802), refusing to extend the exception to agricultural fixtures. American courts, more sympathetic to tenants generally, and farmers in particular, frequently refused to follow the English cases and allowed removal for agricultural and other tenants. See Van Ness v. Pacard, 27 U.S. (2 Pet.) 137 (1829); Whiting v. Brastow, 21 Mass. (4 Pick.) 310 (1826); Holmes v. Tremper, 20 Johns. R. 29 (N.Y. 1822).

281 Ohio St. at 530 (emphasis in the original). Although commonly called the "intention" test, the rule in Teaff $v$. Hewitt has three distinct parts: "1. Actual annexation to the realty, or something appurtenant thereto. 2. Appropriation to the use or purpose of that part of the realty with which it is connected. 3. The intention of the party making the annexation ...." Ibid. The first two criteria are not helpful in landlordtenant cases. Many of the tenant's chattels are annexed sufficiently to satisfy the test as between, e.g., a vendor and a purchaser. See Shields v. Hansen, 201 Wis. 349, 230 N.W. 51 
Because the intention formula included "the relation of the party," it tended to favor removal of a tenant's annexation. As the court explained: "When ... a tenant erects expensive structures ... which can be removed without their destruction or material injury to the freehold, the presumption is a rational one, that it was not the intention of the tenant to make them permanent accessions to the freehold, and thereby donations to the owner of it." 29

The intention test of Teaff has today become the verbal formula by which fixtures cases are resolved. ${ }^{30}$ However, as a practical means of determining when the title of a chattel passes to the landlord, a search for the "intention" of the tenant is not useful." As the court indicated in Teaff,,$^{32}$ this intent is inferred from a substantial loss of value in the chattel or the realty. ${ }^{33}$ Since substantial damage is the criterion by which intent is judged, objective intent is merely a correlative of the extent of injury to the leasehold or the annexation. ${ }^{34}$ Thus, although

(1930). And since the trade fixtures exception is based on fulfilling the economic purpose to which the realty is devoted, the adaptability of the chattel makes the item more rather than less removable.

291 Ohio St. at 531 (emphasis in the original).

30 See, e.g., Anderson-Tully Co. v. United States, 189 F.2d 192 (5th Cir. 1951); Biallas v. March, 305 Mich. 401, 9 N.W.2d 655 (1943); Endler v. State Bank \& Trust Co., 352 Mo. 961, 180 S.W.2d 596 (1944); Handler v. Horns, 2 N.J. 18, 65 A.2d 523 (1949); Berry v. Heinel Motors, Inc., 162 Pa. Super. 52, 56 A.2d 374 (1948); Becwar v. Bear, 41 Wash. 2d 37, 246 P.2d 1110 (1952); Auto Acceptance \& Loan Corp. v. Kelm, 18 Wis. 2d 178, 118 N.W.2d 175 (1962). Some states have statutes on tenants' fixtures, which often are held to be declaratory of the common law intention test. See CAL. Crv. Code $\S 1019$; GA. CODE ANN. §§ 61-109, 61-110 (1951); IDAHO CODE ANN. § 55-308 (1957); ILx. REv. STAT. ch. 80, $\S 34$ (1965); Mont. Rev. Codes ANN. § 67-1307 (1947); N.D. CENT. CODE § 47-06-04 (1960); OKLA. Stat. ANN. tit. 60, $\$ 334$ (1963); R.I. GEN. LAws ANN. § 34-17-2 (1956); S.D. Code $\S 51.1103$ (1939). However, some statutes, listing common law exceptions for articles affixed for purposes of "trade, manufacture, ornament or domestic use" have been interpreted to prevent the removal of agricultural fixtures. See Cotton, supra note 17 , at 518 , and cases cited therein.

31 The intention test is criticized in Horowitz, supra note 3, and Niles, supra note 3.

32 See text accompanying note 29 supra.

33 Substantial damage caused by removal is said to be an "objective inference" of an intention by the tenant permanently to annex the chattel to the premises. See 2 AIGLER, SMith \& TeFe, Property 397 (1960).

34 Similarly, the tenant's "subjective intent" is not controlling, since if he installs his chattel in such a manner that it cannot be removed without substantial damage to itself or the realty, he loses his right of removal regardless of his secret thoughts as to ownership. See 5 American LAw of Property § 19.11, at 40-41 (Casner ed. 1952).

An agreement by the parties concerning the disposition of the chattel will be honored, as when installing the item is part of the consideration for the lease. See, e.g., Warren Post 23, American Legion v. Jones, 302 Ky. 861, 196 S.W.2d 726 (1946). However, there must be a clear indication that a bargain was intended, and general provisions giving the landlord title to all "alterations, additions, and improvements" usually do not transfer title to the tenant's annexations. See Cattie v. Joseph P. Cattie \& Bros., $403 \mathrm{~Pa}$. 161, 168 A.2d 313 (1961); Hartberg v. American Founders' Sec. Co., 212 Wis. 104, 249 N.W. 
courts often speak in terms of "objective intent," the underlying consideration is the amount of damage caused by removing the chattel. ${ }^{35}$

\section{Damage to the Freehold}

The distinction between items found to be attached to the freehold with "a purpose to make them part of the building"36 and items attached without such intent frequently depends, as indicated above, on whether removing the fixture would cause "substantial damage" to the leased property ${ }^{37}$ When the removal of the item would cause the virtual destruction of the premises, as would the removal of an automatic sprinkling system which has become an integral part of the building, courts uniformly hold that title to the item passes to the landlord. ${ }^{38}$ However, when the destruction would be less than total, courts differ over what amount of damage is substantial enough to award the fixture to the landlord. ${ }^{39}$ Some decisions have allowed removal even though it

48 (1933); Comment, Effect of Lessee's "Covenant to Leave Improvements" on the Doctrine of Trade Fixtures, 24 WASH. L. REv. 154, 158-59 (1949); cf. Chicago Title \& Trust Co. v. Fox Theatres Corp., 164 F. Supp. 665 (S.D.N.Y. 1958).

35 Cf. 5 Amierican Law of Property \& 19.11, at 41 (Casner ed. 1952). Another unsuccessful aspect of the intention test is the attempt to formulate a "test of uniform application" for determining when a chattel "becomes realty." See Teaff v. Hewitt, 1 Ohio St. 511, 52425 (1853). But cf. 5 American Law of Property \& 19.12, at 53 \& n.33 (Casner ed. 1952) (stating that there is not one but many concepts of what is a fixture). Attempts to classify a tenant's fixture as real or personal property for all purposes are futile. A tenant's fixture has been held personalty in cases involving attachment by a creditor or trustee in bankruptcy, Freeman v. Dawson, 110 U.S. 264 (1884), and sale under the statute of frauds, Cameron v. Robbins, 141 Ark. 607, 218 S.W. 173 (1920). It has been held realty for purposes of condemnation, In re Allen Street, 256 N.Y. 236, 176 N.E. 377 (1931), and taxation, Bank of America v. County of Los Angeles, 224 Cal. App. 2d 108, 36 Cal. Rptr. 413 (1964). Contra, Sherburne Corp. v. Town of Sherburne, 124 Vt. 481, 207 A.2d 125 (1965). It has been considered a combination of the two in the determination of when the item must be removed from the premises in order for the tenant to retain his title. See Kerr v. Kingsbury, 39 Mich. I50 (1878); 5 American LAw of Property, supra, § 19.Il, at 43-45; Brown, op. cit supra note 3 , § 147. For illogical results caused by the ambiguous nature of a tenant's fixtures, compare Mullins v. Sturgill, 191 Va. 653, 66 S.E.2d 483 (1951) (mining equipment weighing over $61 / 2$ tons was personalty and therefore removable after the expiration of the lease), with In re Slum Clearance, City of Detroit, 332 Mich. 485, 52 N.W.2d 195 (1952) (molten metal and chemical solutions in tanks were compensable in condemnation of the realty).

36 Winnike v. Heyman, 185 Iowa 114, 169 N.W. 631 (1918).

37 See, e.g., Kornblum v. Henry Mangels Co., 167 So. 2d 16 (Fla. Ct. App. 1964) (tenant's refrigeration plant doors removed by using blowtorch); Sanders v. Butte Motor Co., 142 Mont. 524, 385 P.2d 263 (1963) (new room constructed in leased building).

38 Red Diamond Clothing Co. v. Steidemann, 169 Mo. App. 306, 152 S.W. 609 (1912).

39 The application of the "substantial damage" test has brought widespread confusion. See Frost v. Schinkel, 121 Neb. 784, 792-93, 238 N.W. 659, 664 (1931): "Perhaps there are no subjects in law more difficult to deal with than the questions raised as to fixtures. . . . The cases are legion; and each new case seems only the more to disturb any fixed or certain rule that seemed deductible from former cases," 
necessitated taking down a brick wall ${ }^{40}$ or tearing up concrete foundations. ${ }^{41}$ Others have denied removal when only surface damage to a floor was involved. ${ }^{42}$

Much of the confusion regarding "substantial damage" is due to the restrictive nature of the test. Since the possibility of reimbursement by the tenant for injury to the premises is irrelevant in determining whether damage to the freehold is "substantial," 43 the test provides no method for balancing the physical destruction caused by removal against the value of the chattel or its possible alternative use elsewhere. The failure of the courts to arrive at a meaningful definition of "substantial" may be due to their tendency to measure physical damage to the realty in the light of the amount of economic loss involved in removal. ${ }^{44}$

The narrow scope of the "substantial damage" test frequently leads to unsatisfactory results. For example, when a tenant replaces an old article placed on the property by the landlord with a new item of his own, it is generally held that removal of the old item extinguishes the tenant's right to the new one. ${ }^{45}$ Such a reversal of interests, without regard to the values involved, may give an unmerited windfall to the landlord.

A solution to the problems of the "substantial damage" test could be found in making the tenant's right of removing his annexation conditional solely upon his reimbursing the landlord by the amount necessary to restore the premises to their original condition. ${ }^{46}$ Such a

40 Rothery v. Dohrse, 122 Neb. 259, 240 N.W. 296 (1932).

41 Shields v. Hansen, 201 Wis. 349, 230 N.W. 51 (1930).

42 Gordon v. Cohn, 220 Cal. 193, 30 P.2d 19 (1934); Graffell v. Honeysuckle, 30 Wash. 2d 390, 191 P.2d 858 (1948).

43 Alden v. Mayfield, I63 Cal. 793, 127 Pac. 44 (1912); Davidson v. Ginsberg, 190 Iowa 1327, 181 N.W. 661 (1921).

44 The "substantial damage" test seems aimed at retaining on the premises those chattels which it would be economically unwise to remove: the measure of damages for wrongful removal is not only the cost of repairing the premises, but also the value of the items taken. Kornblum v. Henry Mangels Co., 167 So. 2d 16 (Fla. Dist. Ct. App. 1964); Slane v. Curtis, 41 Wyo. 402, 286 Pac. 372, rehearing denied, 41 Wyo. 417, 288 Pac. 12 (1930).

45 Kain v. Coble, 132 N.J.L. 315, 40 A.2d 350, affd, 133 N.J.L. 340, 44 A.2d 211 (1945); McFale v. Rosenblatt, 56 R.I. 120, 184 Atl. 172 (1996); McKemie v. Waldrop, 190 S.W.2d 384 (Tex. Civ. App. 1945); Auto Acceptance \& Loan Corp. v. Kelm, 18 Wis. 2d 178, 118 N.W.2d 175 (1962); Rosenblum v. Terry Carpenter, Inc., 62 Wyo. 417, 174 P.2d 142 (1946).

46 Cf. Uniform CoMmercial Code \& 9-313(5): "[A] secured party . . . may . . . remove his collateral from the real estate but he must reimburse any encumbrancer or owner of the real estate ... for the cost of repair of any physical injury, but not for any diminution in value of the real estate caused by the absence of the goods removed or by any necessity for replacing them."

Where tenants have stated their willingness to pay for damages to the realty caused 
system would protect both the landlord, since the original value of his realty would not be diminished, ${ }^{47}$ and the tenant, since he could freely replace existing items without fear of forfeiture. In addition, it would resolve disputes with a minimum of economic waste, since presumably the tenant would remove only those articles whose resale or use value is greater than the cost of removal plus the cost of repairing the premises. ${ }^{48}$

Although a reimbursement system would resolve most conflicts over fixtures which the tenant seeks to remove from the premises, there may be instances where money damages will not be sufficient to protect the landlord's interests. In such cases, courts should be allowed to fashion suitable equitable relief. An example of such a situation is Woodson Oil Co. v. Pruett, ${ }^{48}$ in which the tenant sought to take its oil well equipment from a producing well at the end of the term. The court, believing that removal of the equipment would permanently destroy

by removal, courts have been liberal in allowing severance. See Kenneally v. Standard Electronics Corp., 364 F.2d 642 (8th Cir. 1966); Rothery v. Dohrse, 122 Neb. 259, 240 N.W. 296 (1932); 399-41 Market Street Corp. v. Darling Stores, 355 Pa. 312, 49 A.2d 686 (1946). Occasionally removal has been conditioned upon payment of damages or other action by the tenant to protect the landlord's interest. See Bergh v. Herring Safe Co., 136 Fed. 368 (2d Cir. 1905); Woodson Oil Co. v. Pruett, 298 S.W.2d 856 (Tex. Civ. App. 1957), discussed in text at note 49 infra. More frequently, however, the right of removal is determined by the amount of damage that would be caused to the realty, without reference to reimbursement. See Alden v. Mayfield, $163 \mathrm{Cal}$. 793, $127 \mathrm{Pac} .44$ (1912), and Davidson v. Ginsberg, 190 lowa 1327, 181 N.W. 661 (1921), stating that it is irrelevant that the tenant is willing to repair the damage caused by removal.

47 In Dudzick v. Lewis, 175 Tenn. 246, 133 S.W.2d 496 (1939), the court considered the premises damaged because removal of the annexation reduced the value of the property. Under the proposed test, the value to be protected is that of the original leasehold, ordinary wear and tear excepted. An agreement between the parties concerning the disposition of an annexation will be respected, however. $C f$. note 34 supra.

48 If the value of the chattel as part of the premises is great enough, the tenant will wish to sell it to the landlord. See text accompanying notes 72-74 infra.

An alternative to the rule proposed above would be to compel the landlord to pay the tenant the value of chattels affixed to the premises at the end of the term. While this might encourage high level maintenance of the leasehold (since the tenant would be compensated for the unexpired value of improvements at the end of the term), it would unnecessarily curtail the landlord's ability effectively to utilize the land after the expiration of the lease. In order to change the use to which the premises are devoted, the landlord would either have to insert a provision in the lease providing for removal of those improvements he did not wish to retain, or else take a loss on attached chattels not suited to the new use of the premises by scrapping them. Thus, the landlord must either have anticipated the new use in advance or pay the unnecessary cost of chattels he will not use. Flexibility in land use would consequently be restricted.

Under the proposed rule, high level maintenance of the premises can still be encouraged. At any time during the period of the lease, the landlord can bargain for improvements whose life expectancy will extend beyond the leasehold term.

49298 S.W.2d 856 (Tex. Civ. App. 1957). See also Eubank v. Twin Mountain Oil Corp., 406 S.W.2d 789 (Tex. Civ. App. 1966). 
the well, refused to allow removal until after the well stopped pro-. ducing. However, it ordered that until such time the lessee be paid a reasonable rental for the equipment.

\section{Damage to the Attached Chattel}

The criterion of "substantial damage" is applied by some courts not only in cases of damage to the realty, but also where the attached chattel itself is injured by removal. ${ }^{50}$ When the affixed item can be removed only by tearing it to rubble, as with a large building with concrete foundations, the addition has been considered a permanent part of the realty. ${ }^{51}$ Similarly, if the value of the chattel when removed is considerably less than its value when left in place, as with an item especially designed for the particular premises, ${ }^{52}$ removal has frequently been prohibited. In one case, an elaborate air conditioning unit was installed in the premises in such a manner that forty per cent of the cost of installation would be lost in removing it. Although the court found that the system could be removed without substantial damage to the building, it held that the unit was a permanent part of the realty. ${ }^{53}$

An apparently parallel line of authority has rejected loss of value in the attached item as a criterion for transferring ownership to the landlord. ${ }^{54}$ Courts have allowed tenants to destroy entire buildings, ${ }^{55}$ even when the only value in so doing was for wrecking purposes. ${ }^{56}$ In Cattie v. Joseph P. Cattie \& Brothers, ${ }^{57}$ the court permitted an industrial crane to be torn apart and sold as scrap. It was irrelevant that the destruction reduced the value of the equipment from $\$ 69,200$ to $\$ 10,414 . .^{58}$

50 See Della Corp. v. Diamond, 210 A.2d 847 (Del. 1965); John P. Squire \& Co. v. City of Portland, 106 Me. 234, 76 Atl. 679 (1909); Collamore v. Gillis, 149 Mass. 578, 22 N.E. 46 (1889); Delano v. Tennent, 138 Wash. 39, 244 Pac. 273 (1926).

51 Haskins v. Kelly, 192 Misc. 366, 78 N.Y.S.2d 912 (1948). Contra, Dickerman v. Town of Pittsford, 116 Vt. 563, 80 A.2d 529 (1951).

52 Della Corp. v. Diamond, 210 A.2d 847 (Del. 1965) (carpeting cut specially for the premises not removable).

53900 Main, Inc. v. Houston, 150 S.W.2d 468 (Tex. Civ. App. 1941).

54 See, e.g., Andrews v. Williams, 115 Colo. 478, 173 P.2d 882 (1946); Baker v. McClurg, 198 IIl. 28, 64 N.E. 701 (1902).

55 Cameron v. Oakland County Gas \& Oil Co., 277 Mich. 442, 269 N.W. 227 (1936); General Petroleum Corp. v. Schefter, 141 Ore. 349, 16 P.2d 645 (1932); cf. Van Ness v. Packard, 27 U.S. (2 Pet.) 137, 146 (1829), applying the trade fixtures exception: "[T] question, whether removable or not, does not depend upon the form or size of the building, whether it has a brick foundation or not, or is one or two stories high, or has a brick or other chimney. The sole question is, whether it is designed for purposes of trade or not."

56 See Cameron v. Oakland County Gas \& Oil Co., 277 Mich. 442, 462, 269 N.W. 227, 234 (1936), where the dissent pointed out that the only value the tenant's building would have when severed from the land was scrap.

$57403 \mathrm{~Pa} .161,168$ A.2d 313 (1961).

$58 \mathrm{Id}$. at $163,168 \mathrm{~A} .2 \mathrm{~d}$ at 314. 
The decisions recognizing substantial loss of value in the fixture as a basis for transferring ownership to the landlord are founded on a policy of minimizing the economic loss caused by dismantling the annexation. ${ }^{59}$ It should be noted that the interest protected in these cases is not that of the landlord, since even if removal is allowed the landlord must recover the premises in the same condition in which they were let. ${ }^{60}$ Rather, the rule rests on public policy considerations of minimizing the loss involved in separating attached chattels from the land. Thus, the test of substantial damage to the attached item is based on the same considerations that led early English courts to apply the attachment test in contests between heirs and executors.

The criterion of "substantial damage" to the attached chattel, like the attachment rule in English inheritance cases, tends to reduce the loss involved in the operation of a given economic unit. ${ }^{61}$ However, the consequences of making a tenant's annexations part of the realty differ from those in the inheritance cases. In the latter, the court's function is to divide items among parties who previously had no interest in them. The landlord-tenant relationship, on the other hand, is not designed to effect a transfer of interest to the landlord. Awarding the landlord the tenant's chattel not only gives him an unmerited and unintended acquisition of property, it also imposes financial loss on the tenant. If the public interest in preserving land resources is to be implemented in landlord-tenant cases, its weight must be great enough to override the harsh effect on tenants. ${ }^{62}$

The rule denying removal when substantial injury to the attached items occurs is based on two assumptions: (l) that keeping the fixture on the land will conserve economic resources; and (2) that the saving of resources justifies depriving the tenant of the fixture. In order to evaluate the merits of the nonremoval rule, each of these assumptions must be examined.

59 In Whitehead v. Bennett, 27 L.J. Ch. (n.s.) 474, 475 (1858), the court held that while the tenant was allowed to dismantle and remove a small machine which could easily be reassembled elsewhere, he could not remove a brick building, presumably because the court felt that the economic waste involved in reducing the building to its primary materials would be excessive, Accord, Collamore v. Gillis, 149 Mass. 578, 22 N.E. 46 (1889).

60 See Baker v. McCurg, 198 Ill. 28, 35, 64 N.E. 701, 704 (1902); "The landlord is not affected by an injury done by the tenant to the latter's own property."

61 See note 7 supra and accompanying text.

62 The economic soundness of the conservation policy as applied to tenants is open to question. Unlike the heir or executor in the inheritance case, the tenant owns the chattel in question. The premise that society's interests can be advanced by an involuntary transfer of ownership seems to contradict the classical economic assumption that the owner of a unit of property is best able to determine the economically appropriate use of that property. When the conservation policy is applied to landlord-tenant cases, society's interest in preserving the given economic unit must be weighed against society's interest in preserving unimpaired investment and the free flow of capital. 
1. The Mechanics of Conserving Resources. In certain circumstances the law recognizes that removing a chattel affixed to the land will substantially reduce the item's value. Where real property is condemned, tenants may be awarded damages for chattels which admittedly would be removable from the premises as personalty at the end of the lease. ${ }^{63}$ Similarly, where realty is assessed for taxation purposes, a tenant's removable annexation may be of so much value in relation to the rest of the property as to be taxable as part of the land. ${ }^{64}$

A distinction must be made, however, between the condemnation and taxation cases, where the value of the chattel as part of the economic unit is considered at some point during the lease period, and the "substantial damage" criterion, which deals with this value at the end of the term. ${ }^{65}$ Although a chattel's value as part of the premises may be high during the lease, it does not follow that it will remain so after the term. ${ }^{66}$

At the time when the attachment rule, with its emphasis on preserving land resources, was developed in England, there frequently was little difference between the value of an attached chattel during and

63 See United States v. 15.3 Acres of Land, I54 F. Supp. 770 (M.D. Pa. 1957); Gilbert v. State ex rel. Morrison, 85 Ariz. 321, 338 P.2d 787 (1959); Marraro v. State, 12 N.Y.2d 285, 189 N.E.2d 606, 239 N.Y.S.2d 105 (1963); Milburn By-Products Coal Co. v. Eagle Land Co., 141 W. Va. 866, 93 S.E.2d 231 (1956). In In re Acquiring Certain Property on the North River in the City of New York, 118 App. Div. 865, 866-67, 103 N.Y.S. 908,909 (1907), the court stated: "It would be manifestly unjust to treat such property as personal property, when its value after it was severed from the building would be a very small percentage of its value as a part of the building for the use of the tenants in the business which they were conducting."

64 See Pajaro Valley Bank v. County of Santa Cruz, 207 Cal. App. 2d 621, 24 Cal. Rptr. 639 (1962).

65 The condemnation cases differ not only as to the time at which the value is considered, but also as to the tenant's anticipated use of the chattel, and therefore its value to him. At the expiration of the lease, the tenant has chosen to remove the fixture and eliminate its integrated value. In the condemnation case, however, he has not made such a choice, and presumably he does not wish to see the item removed. The results in both cases tend to favor the tenant, by considering the item removable "personalty" in landlord-tenant cases, and by compensating the tenant for its value as "realty" in condemnation proceedings. See generally 4 NicHols, EMINENT DoMAIN § 13.12 (1962); Comment, Compensation for a Lessee's Trade Fixtures in Condemnation Proceedings, 1966 WIs. L. REv. 1215 (1966).

66 But see Matter of the City of New York (Allen Street), 256 N.Y. 236, 176 N.E. 377 (1931), refusing to consider as a factor in assessing the value of a chattel the fact that the lease was due to expire in five months. The court pointed out that the expiration date of the lease was not necessarily the time when the chattel would be removed: "[P]erhaps the parties might have chosen to preserve that value either by renewal of the lease or by transfer of title to the fixtures from the tenant to the owner of the fee. Choice lay with the tenant and landlord, and how that choice would have been exercised rests in speculation which does not concern the courts in this jurisdiction." Id. at 249, 176 N.E. at 381. 
after the lease. According to the customs of the period, commercial leases were usually short term. ${ }^{67}$ If a tenant installed an item such as a building that involved large capital expenditure, the value of the chattel was often considerable after the expiration of the term. If the parties failed to renew the lease, the loss involved in removal justified transferring ownership to the landlord.

The modern developments of long term commercial leases and improved capital planning techniques have minimized the value of the affixed item after the end of the lease. With the ability to bargain for a leasehold term that matches the life expectancy of his additions, a tenant today will adjust the period of the lease so that he obtains the maximum value from his most expensive inputs of production. ${ }^{68}$ Simply stated, a tenant normally will not put a valuable machine with a life expectancy of fifty years in a building which he leases for ten years. ${ }^{69}$

Because of the minimal value of the addition at the end of the lease, a chattel remaining on the land after the term is likely either to have a short life expectancy or to be valuable principally as scrap. If scrap is the principal value of the chattel, it makes no difference in terms of society's resources whether this value is realized by the landlord or the tenant. Since there is no saving of economic resources by transferring ownership to the landlord, the justification for refusing to permit the tenant to remove the item is absent.

Certain businesses, such as small retail stores, often take leases on a short term basis. In these cases, it is likely that chattels whose life expectancy is greater than the term of the lease will be affixed to the land. It might be argued that in such instances the conservation policy of preserving the value of the chattel as part of the premises should be given effect. However, it is in these cases that the considerations of allowing removability which underlie the old trade fixtures rule $e^{70}$ are most important. The retail merchant who takes a short term lease frequently is in need of credit. Making his annexations the property of the landlord would hamper his dealings with creditors and restrict his business activity. Since the fixtures installed by short term lessees are unlikely to be of considerable value, the conservation policy of making such annexations permanent would appear to be outweighed by its detrimental effect on the tenant's ability to operate on credit. ${ }^{71}$

67 See note 17 supra.

68 Alternatively, he will bargain for a lease that gives him an option to renew.

69 This is likely to be true whether or not the tenant is allowed to remove the item at the end of the lease, since he wishes to avoid the cost of dismantling, removing, and reinstalling the item. However, if the tenant does install an item which he plans to remove, it will be one whose removability can be effected with minimal cost.

70 See text accompanying notes 12-20 supra.

71 Creditors have frequently claimed a tenant's annexations to satisfy their claims. 
The rule transferring ownership of a chattel to the landlord when removal would cause loss of value is based on the proposition that a valuable annexation should not be removed from the premises because it is part of the operating land unit. Courts applying the rule assume that a tenant will take from the premises all items to which he has title. However, if the value of the chattel as part of the land is great enough, both the landlord and the tenant will want to keep it on the premises. The landlord will wish to buy the annexation, since its presence enhances the value of his property. The tenant will be willing to sell it, since he will not have to bear the cost of dismantling, removing, and reinstalling the item..$^{72}$ It is thus likely that when the value of the fixture is great, it will remain on the premises despite the tenant's ownership, ${ }^{73}$ and the loss entailed by removal will be avoided. ${ }^{74}$

See Uncle Sam Oil Co. v. Union Petroleum Co., 90 Okl. 135, 216 P. 443 (1923); Hartberg v. American Founders Securities Co., 212 Wis. 104, 249 N.W. 48 (1933) (attaching creditors). Ridgefield Investors v. Holloway, 75 So. 2d 208 (Fla. 1954); Butler v. Butler's Diner, 81 R.I. 43, 98 A.2d 875 (1953); Auto Acceptance \& Loan Corp. v. Kelm, 18 Wis. 2d 178, 118 N.W.2d 175 (1962) (chattel mortgagees). Kenneally v. Standard Electronics Corp., 364 F.2d 642 (8th Gir. 1966) (conditional vendor).

Under the Uniform Commercial Code, it will become easier in the future for creditors to obtain security interests in fixtures. See generally Coogan, Security Interests in Fixtures Under the Uniform Commercial Code, 75 HARV. L. REv. 1319 (1962); Coogan, FixturesUniformity in Words or in Fact?, 113 U. PA. L. REv. 1186 (1965); Gilmore, The Purchase Money Priority, 76 HARv. L. REv. 1333 (1963); Kripke, Fixtures Under the Uniform Commercial Code, 64 Colvm. L. Rev. 44 (1964); Shanker, An Integrated Financing System for Purchase Money Collateral, 73 YALE L.J. 788 (1964). However, a tenant's fixtures may well prove a source of difficulty because of the conflicting rules on financing chattels and fixtures. Compare Uniform CoMmercial CoDE \& 9-312 with \& 9-313. Although a tenant's annexations will normally be considered chattels, see Kripke, supra at $66-69$, peculiarities of local law may render them "realty" and subject to claims by holders of interest in the freehold. See Adams v. Chamberlin, 54 Ga. App. 459, 188 S.E. 550 (1936), and Guthrie v. Jones, 108 Mass. 191 (1871), stating that a tenant's removable annexations are "realty" while in place, and authorities cited notes $37,38,42$, and 43 , supra, where annexations are considered "realty" under the "substantial damage" test. In addition, the tenant may purchase the land from the landlord, rendering his annexations "fixtures" as against a subsequent mortgage of the realty. See Thompson \& Co. v. Lewis, 120 Ark. 252, 179 S.W. 343 (1915). The problem of security interests in a tenant's annexations is one of the many unresolved difficulties under the fixtures section of the Code. See articles cited supra.

72 It is also possible that the parties will renew the lease or that the tenant will purchase the freehold from the landlord.

73 Controversies over a tenant's annexations frequently involve determination of title while the chattel is still on the premises. Banks v. Clintworth, 201 Cal. App. 2d 789, 20 Cal. Rptr. 431 (1962); Woodson Oil Co. v. Pruett, 298 S.W.2d 856 (Tex. Civ. App. 1957) (declaratory judgment). Frost v. Schinkel, 121 Neb. 784, 238 N.W. 659 (1931); Killian v. Hubbard, 69 S.D. 289, 9 N.W.2d 700 (1943) (injunction against removal). Eubank v. Twin Mountain Oil Corp., 406 S.W.2d 789 (Tex. Civ. App. 1966) (suit to quiet title).

74 The ability of the landlord and tenant to determine rights in the chattel may lead to harassment or coercion by one of the parties. In Cattie v. Joseph P. Cattie \& Bros., $403 \mathrm{~Pa}$. 161, $168 \mathrm{~A} .2 \mathrm{~d} 313$ (1961), discussed at note 58 supra, the tenant scrapped his annexations of $\$ 10,414$ rather than sell them to the landlord for $\$ 20,000$. Id. at $163-64,168$ 
In conclusion, it appears that the rule making an attached item irremovable if severing it would cause damage to the item fails to fulfill the purpose of conserving land resources. Due to modern leasing and input practices the most expensive and valuable additions, which are the ones society has the most interest in preserving, are likely to be valuable only as scrap at the end of the term. In businesses where short term leases are the prevailing practice, considerations of encouraging economic activity weigh against awarding attached chattels to the landlord. Finally, it should be noted that giving the tenant the right to remove his annexations does not necessarily mean that they will be taken from the land, since the landlord usually may purchase the items at the end of the term.

2. The Policy of Conservation. The rule prohibiting the tenant from removing a fixture when the item would be damaged is similar to the English attachment rule as a device for promoting the public policy of preserving land resources. ${ }^{75}$ The development of this public policy occurred during a period when the productivity of a unit of land was considerably less than it is today. At the time when the attachment rule was used to make a tenant's annexation realty, the value of a machine or a building annexed to the freehold was considerable in terms of the amount of wealth the property was capable of yielding. In relation to the productivity potential of the land, the removal of an affixed chattel was a great loss.

Modern technological advances ${ }^{76}$ have lessened the consequences to society of the removal of a tenant's annexation. The improved efficiency and greater productivity brought by technological development have made possible a higher economic return to a given unit of land. ${ }^{77}$ Because of the increased productivity potential of the land, the wealth lost by the tenant's removal represents a smaller proportion of what the land is capable of producing than it did during the period of the attachment test. Thus, the saving of society's land resources through a non-removal rule is now reduced.

In view of the diminished significance of the law of fixtures as a device for preserving land resources, the rule prohibiting the tenant from removing a chattel when damage to the item would result should

A.2d at 314. However, the possibility of harassment exists whether or not the tenant has the right to remove his annexations. In Cattie, for example, the landlord apparently terminated the lease in order to acquire title to the items.

75 See text accompanying notes 7-9 supra.

76 Technological change may be defined as "a change in the parameters of a production function resulting directly from the use of new knowledge." See Stout \& Ruttar, Patterns of Technological Change in American Agriculture, 40 J. FARM ECON. 196-207 (1958).

77 Cf. Baker, Productivity Potentials of New Technologies Related to Land, in MODERN LAND POLICY 103, 104-07 (1960). 
be reconsidered. Refusing the tenant the right of removal not only deprives him of his property, it also has the collateral disadvantage of discouraging his economic activity. ${ }^{78}$

\section{CONCLUSION}

The law of fixtures in landlord-tenant relations serves two purposes, protection of the landlord and conservation of land resources. In both these objectives, the current state of the law is unsatisfactory: protection of the landlord could more effectively be accomplished by making the tenant's right to remove his fixtures conditional on reimbursing the landlord for physical damage caused by severance; and the policy of preserving land resources is not only being unsuccessfully pursued, but it is of dubious importance in view of modern productive capacity. 